\title{
Trophic structure of the marine food web at the Prince Edward Islands (Southern Ocean) determined by $\delta^{13} \mathrm{C}$ and $\delta^{15} \mathrm{~N}$ analysis
}

\author{
S. Kaehler ${ }^{1, *}$, E. A. Pakhomov ${ }^{2}$, C. D. McQuaid ${ }^{1,2}$ \\ ${ }^{1}$ Department of Zoology and Entomology and ${ }^{2}$ Southern Ocean Group, Rhodes University, PO Box 94, Grahamstown 6140, \\ South Africa
}

\begin{abstract}
The origins (autochthonous or allochthonous) and pathways of organic matter in various marine communities were investigated in the vicinity of the sub-Antarctic Prince Edward Islands using stable-isotope analysis. Four major assemblages, comprising zooplankton, kelp-associated species, inter-island and nearshore benthos, were considered. Despite consumers exhibiting a predictable enrichment in $\delta^{13} \mathrm{C}$ and $\delta^{15} \mathrm{~N}$ with trophic position, only the zooplankton community displayed distinct trophic levels. The benthic and the kelp-associated communities showed trophic continua. Both pelagic (zooplankton) and benthic inter-island communities ultimately derived their diets from phytoplankton (associated with surface-water POM). However, planktonic grazers fed primarily on allochthonous nano- and pico-plankton, while inter-island benthos seemed to rely mostly on microphytoplankton derived from autochthonous blooms. In contrast, kelp-associated animals derived a high proportion of their diet from kelp. The nearshore benthic community had an intermediate position between kelp-associated and inter-island communities. While POM was of primary importance, kelp-derived organic matter accounted on average for $>30 \%$ of the nearshore animals' diet. Findings of the present study indicate for the first time that autochthonous sources of organic matter (e.g. kelp-derived and microphytoplankton blooms), are important components of the diets of all but the zooplankton community at the sub-Antarctic Prince Edward Islands.
\end{abstract}

KEY WORDS: Marine food web $\cdot$ Stable isotopes $\cdot$ Sub-antarctic $\cdot$ Kelp $\cdot$ POM

\section{INTRODUCTION}

The Prince Edward Archipelago (46 $70^{\prime} \mathrm{S}, 37^{\circ} 70^{\prime} \mathrm{E}$; south Indian Ocean) comprises Marion Island and the smaller Prince Edward Island. While together their total extent barely exceeds $310 \mathrm{~km}^{2}$, they support in excess of 5 million birds and seals during the breeding season (Williams et al. 1979, Pakhomov \& Froneman 1999). In a region of otherwise low productivity, this profusion of land-based marine predators as well as the presence of a rich inter-island benthic community raises the question as to the origin of their food (Pakhomov \& Froneman 1999).

\footnotetext{
*E-mail: s.kaehler@ru.ac.za
}

While many of the land-based top predators forage far from the islands, others feed relatively close inshore (Pakhomov \& Froneman 1999). Recent studies have indicated that the ability of the islands to support high densities of inshore feeders probably depends on energy inputs from 2 sources. One source of energy is external to the island system itself, and is driven by constant advection from the west and mechanical concentration of allochthonous prey species between and in the lee of the islands (Perissinotto et al. 1990, Perissinotto \& McQuaid 1992, Pakhomov \& Froneman 1999). It has been suggested that upstream zooplankton and micronekton that migrate into the upper water layers at night are carried over the shallow island shelf. At dawn, unable to descend into deeper waters, they become trapped within the forag- 
ing depths of visual predators (Perissinotto \& McQuaid 1992). The second source of energy is autochthonous and reflects a localised enhancement of primary productivity, termed the 'island mass effect' (Allanson et al. 1985). Two aspects of the island mass effect are important: primary production is enhanced and the size composition of the phytoplankton community differs from that of offshore waters. Phytoplankton biomass in the vicinity of the islands is enhanced due to increased vertical stability and availability of nutrients (especially reduced nitrogen) generated by freshwater run-off (Allanson et al. 1985, Ismail 1990) as well as the presence of anti-cyclonic eddies which retain water over the island shelf (Perissinotto \& Duncombe Rae 1990). Increased productivity primarily affects the large microphytoplankton, and algal blooms around the islands have been recorded on many occasions (Allanson et al. 1981, 1985, Boden 1988, Perissinotto \& Duncombe Rae 1990). Inshore micro-algal blooms may directly or indirectly enhance growth and abundance of important prey species such as the caridean shrimp Nauticaris marionis (Perissinotto \& McQuaid 1990).

In addition to enhanced phytoplankton production around the islands, there is substantial macroalgal productivity associated with high densities of kelps. In the infralittoral fringe, the kelp Durvillaea antarctica may reach densities of 28 to $161 \mathrm{~kg}$ wet mass $\mathrm{m}^{-2}$ (Haxen \& Grindley 1985), while at depths $>5 \mathrm{~m}$ the endemic kelp Macrocystis laevis predominates $\left(\sim 12 \mathrm{~kg} \mathrm{~m}^{-2}\right.$, Attwood et al. 1991, Beckley \& Branch 1992). Macroalgal productivity per unit area is estimated at 2 to 3.5 times that of the phytoplankton, yet it has been perceived as unlikely to be important in the marine food-web around Marion Island as most of the material produced is thought to be washed ashore or transported away from the islands (Beckley \& Branch 1992).

Input of allochthonous zooplankton, enhanced local phytoplankton production and possibly high productivity of kelps are all likely to facilitate high consumer biomass. There have been a number of studies, based primarily on gut-content analysis, of planktonic grazers and carnivores around the islands (e.g. Froneman \& Pakhomov 1998, Pakhomov et al. 1999b). However, overall trophic pathways are still poorly understood and there is, as yet, little understanding of the degree to which local food webs are ultimately dependent on the different sources of primary production.

Studies of stable isotopes can provide information on the origins and pathways of organic matter, as the isotopic composition of consumers is closely related to that of their diet (de Niro \& Epstein 1976, Wada et al. 1991). In marine consumers, depending on the tissue type sampled, ${ }^{13} \mathrm{C}$ typically becomes enriched by $\sim 1 \%$ (Fry \& Sherr 1984, France \& Peters 1997) and ${ }^{15} \mathrm{~N}$ by
3 to $4 \%$ (Owens 1987, Wada et al. 1991) relative to their prey. $\delta^{13} \mathrm{C}$ and $\delta^{15} \mathrm{~N}$ can, therefore, be used to determine both the consumer's diet and its trophic position within the food web.

The aim of this study was to elucidate in greater detail the trophic pathways of various marine communities (i.e. zooplankton, inter-island benthos, nearshore benthos and kelp-associated species) by use of $\delta^{13} \mathrm{C}$ and $\delta^{15} \mathrm{~N}$ analysis. Particular emphasis was placed on the relative importance of different sources of organic matter in supplying the marine food web in the vicinity of the Prince Edward Islands.

\section{METHODS}

Sampling and stable-isotope analysis. Plant, animal and particulate organic matter (POM) samples from the vicinity of Marion Island were obtained during the fourth Marion Island Oceanographic Survey cruise (MIOS IV) from April to May 1999. A variety of techniques were employed to obtain samples from both benthic and pelagic communities (see below; for sample locations see Fig. 1).

Phytoplankton could not be sampled directly, but made up a large proportion of surface-water POM ( 70 to $80 \%$; Kaehler unpubl. data). For this reason, stableisotope signatures of POM (consisting primarily of

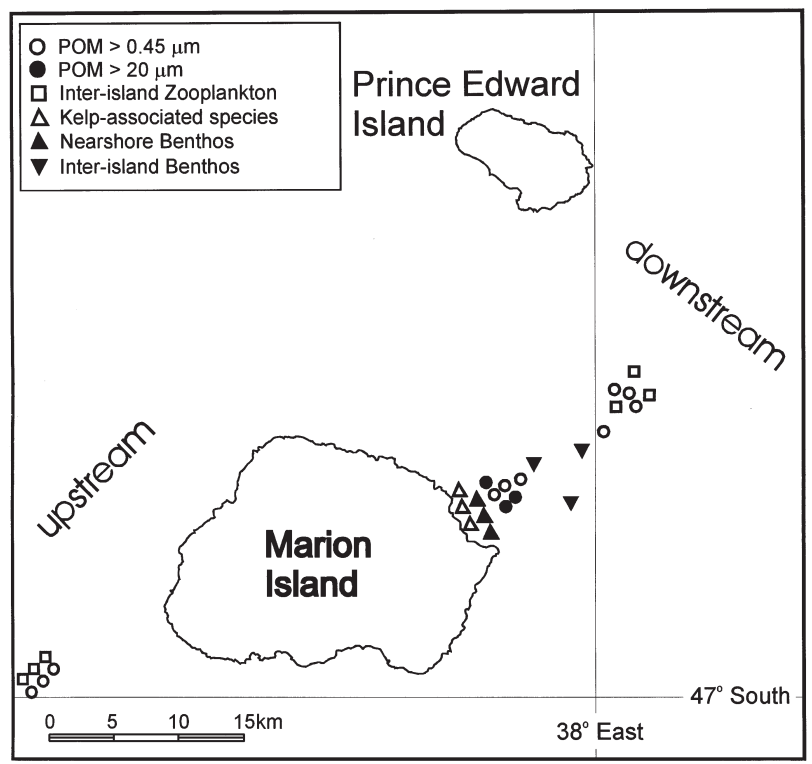

Fig. 1. Location of sampling sites in vicinity of Prince Edward Islands (Southern Ocean). Westerly flow of the Antarctic Circumpolar Current continuously carries allochthonous zooplankton and nano- and pico-phytoplankton over the island shelf. Autochthonous sources of primary production occur in the form of micro-phytoplankton blooms (in the inter-island sea and the lee of the islands) and nearshore kelp forests 
phytoplankton and some protozooplankton), rather than of phytoplankton, were used to describe planktonic sources of organic matter. 'Mixed' POM ( $>0.45 \mu \mathrm{m}$ particle size, containing the full size range of phytoplankton) was obtained by filtering 51 of surface water from upstream $(\mathrm{n}=3)$, downstream $(\mathrm{n}=4)$ and close to the islands $(\mathrm{n}=3)$, through pre-combusted GFF filters (at $<5 \mathrm{~cm} \mathrm{Hg}$ ), followed by manual removal of all visible zooplankton and other contaminants under a dissecting microscope ( $\times 120$ magnification). Metazooplankton was successfully removed as shown by SEM microscopy of filter sections. 'Micro' POM (>20 $\mu \mathrm{m}$, dominated by large, typically autochthonous chain-forming diatoms) was obtained by filtering approximately 151 of surface water through $20 \mu \mathrm{m}$ Nitex mesh ( $\mathrm{n}=3$, at $<5 \mathrm{Hg}$ ) and removing the filtered material, before further preparation. All visible zooplankton was removed under a dissecting microscope (see above). A preliminary investigation of surface waters (Nikon TMS inverted microscope; $\times 400$ ) determined the most abundant planktonic species composing the micro $(>20 \mu \mathrm{m})$ and nano/pico $(>0.45 \mu \mathrm{m}$ $<20 \mu \mathrm{m}$ ) size fractions of the POM.

Macroalgal samples were obtained from near-shore kelp beds and from benthic samples. Kelp samples consisted of a range of young and old fronds of Macrocystis laevis as well as kelp detritus $(\mathrm{n}=11)$.

Pelagic zooplankton was sampled by Bongo-nets retrieved from 140 to $300 \mathrm{~m}$ depths both upstream and downstream of the island. The benthos was sampled by dredging at depths of 100 to $170 \mathrm{~m}$ in the interisland area and using a grab, at depths of 45 to $70 \mathrm{~m}$, closer to the island. Organisms associated with the kelp bed (attached to Macrocystis laevis fronds) were collected by dragging a hand-held plankton net through the kelp from a motorised dinghy.

After collection, animal samples were immediately dissected. Whenever possible, the muscle tissue of benthic and pelagic animals was used for analysis. For a small number of species, however, dissection was impossible (e.g. sponges, hydroids, small copepods). For these, living organisms were left overnight in filtered seawater to allow evacuation of the gut contents. Subsequently, whole or partial organisms were used for isotope determination. Macroalgal samples were washed in distilled water to remove epiphytes (although with the exception of bivalves and hydroids no macroscopically visible epiphytes were evident), and whole sections of fronds were prepared for analysis. All samples were then frozen at $-18^{\circ} \mathrm{C}$ for storage.

After return to the laboratory, organisms were dried for $24 \mathrm{~h}$ at $50^{\circ} \mathrm{C}$. Animal tissues from a minimum of 3 organisms (all from the same collection site) were pooled for each analysis. With the exception of Nematocelis megalops, Sergestes sp., Limopsis marionensis,
Perioblaster foliculatus and Trophon declinans (each of which was found in only 1 collection), 3 replicates were prepared for analysis (each from a different collection site). Subsequently, samples were crushed and homogenised with a pestle and mortar and treated with $2 \mathrm{~N}$ $\mathrm{HCl}$ to remove carbonates. In order to minimise variation in the isotope signature due to species' differences in the concentration of isotopically lighter lipids, samples were defatted in a solution of methanol, chloroform and water (2:1:0.8) after the method of Bligh \& Dyer (1959). After a final wash in distilled water, samples were once more dehydrated, and small quantities from each sample ( 0.45 to $0.6 \mathrm{mg}$ for animal tissues, 1 to $2 \mathrm{mg}$ for macroalgae and 15 to $18 \mathrm{mg}$ of GFF filter) were weighed into tin combustion cups.

$\delta^{13} \mathrm{C}$ and $\delta^{15} \mathrm{~N}$ determination was carried out on a Finnigan-MAT 252 stable light-isotope mass spectrometer, after sample combustion in an on-line Carlo-Erba preparation unit. Merck gelatine was used as an internal standard, calibrated against several International Atomic Energy Agency reference materials. Results are expressed in the standard delta notation, as $\delta X=$ $\left(\left[R_{\text {sample }} / R_{\text {standard }}\right]-1\right) \times 1000$, where $X=$ the element in question and $R=$ the ratio of the heavy over the light isotope. Repeated analyses of homogeneous material yielded a standard deviation of $0.04 \%$.

Data analysis. The vast majority of all photosynthesised carbon in the seas around the Prince Edward Islands originates from either kelp or phytoplankton (associated with POM). The relative contribution of these 2 carbon sources to consumers in the different benthic and pelagic communities may, therefore, be calculated by using a simple mixing model for a 2-source system (Bustamante et al. 1996). While in principle the same calculation could also be used to determine the source of assimilated nitrogen, in this study the lack of $\delta^{15} \mathrm{~N}$ values for primary producers precludes such analysis (see 'Results'). The contribution of kelp-derived carbon to primary consumers may be determined as follows,

$$
\begin{aligned}
\% \mathrm{C}_{\text {kelpderived }}= & \left(\delta^{13} \mathrm{C}_{\text {consumer }}-\delta^{13} \mathrm{C}_{\mathrm{POM}}-I \times 100\right) / \\
& \left(\delta^{13} \mathrm{C}_{\text {kelp }}-\delta^{13} \mathrm{C}_{\mathrm{POM}}\right)
\end{aligned}
$$

where $I$ is the average post-photosynthetic fractionation of $\delta^{13} \mathrm{C}$ per trophic level. In the current study, the trophic enrichment of $\delta^{13} \mathrm{C}$ and $\delta^{15} \mathrm{~N}$ was calculated for pelagic consumers, as this was the only community exhibiting distinct trophic levels. The chaetognath Sagitta gazellae, which is known to feed primarily on small copepods and pteropods (Froneman \& Pakhomov 1998), exhibited a 2.30 and $3.82 \%$ enrichment over their food source for $\delta^{13} \mathrm{C}$ and $\delta^{15} \mathrm{~N}$ respectively. Enrichment from the second trophic level to higher order predators such as decapods and fish averaged $1.62 \%$ for $\delta^{13} \mathrm{C}$ and $4.41 \%$ for $\delta^{15} \mathrm{~N}$. An average $\delta^{13} \mathrm{C}$ 
enrichment ( $I$ ) of $1.96 \%$ per trophic level was therefore used in Eq. (1).

Because of small sample sizes, statistical analyses could not be performed between individual species. Instead, mean values $( \pm \mathrm{SD})$ are presented graphically (see Figs. 2 to 4 ).

\section{RESULTS}

Because of the small sample volumes of POM obtained by filtration, $\delta^{15} \mathrm{~N}$ could not be determined for the POM by available methods. Consequently, only $\delta^{13} \mathrm{C}$ was used to estimate the importance of different primary producers to the consumers.

The 2 main types of primary producers found in the vicinity of the Prince Edward Islands had distinctly different $\delta^{13} \mathrm{C}$ signatures (i.e. kelp $=14.38 \pm 3.09 \%$ and phytoplankton associated with mixed $\mathrm{POM}=$ $24.84 \pm 0.62 \%$ o). Mixed POM $(>0.45 \mu \mathrm{m})$ obtained upstream and downstream of the islands exhibited similar $\delta^{13} \mathrm{C}$ values, but nearshore POM was significantly enriched $(\sim 1 \%)$ compared to offshore POM (StudentNewman-Keuls test after 1-way ANOVA, df $=7, F=$ $0.123, p=0.0028)$. Furthermore, different size frac-

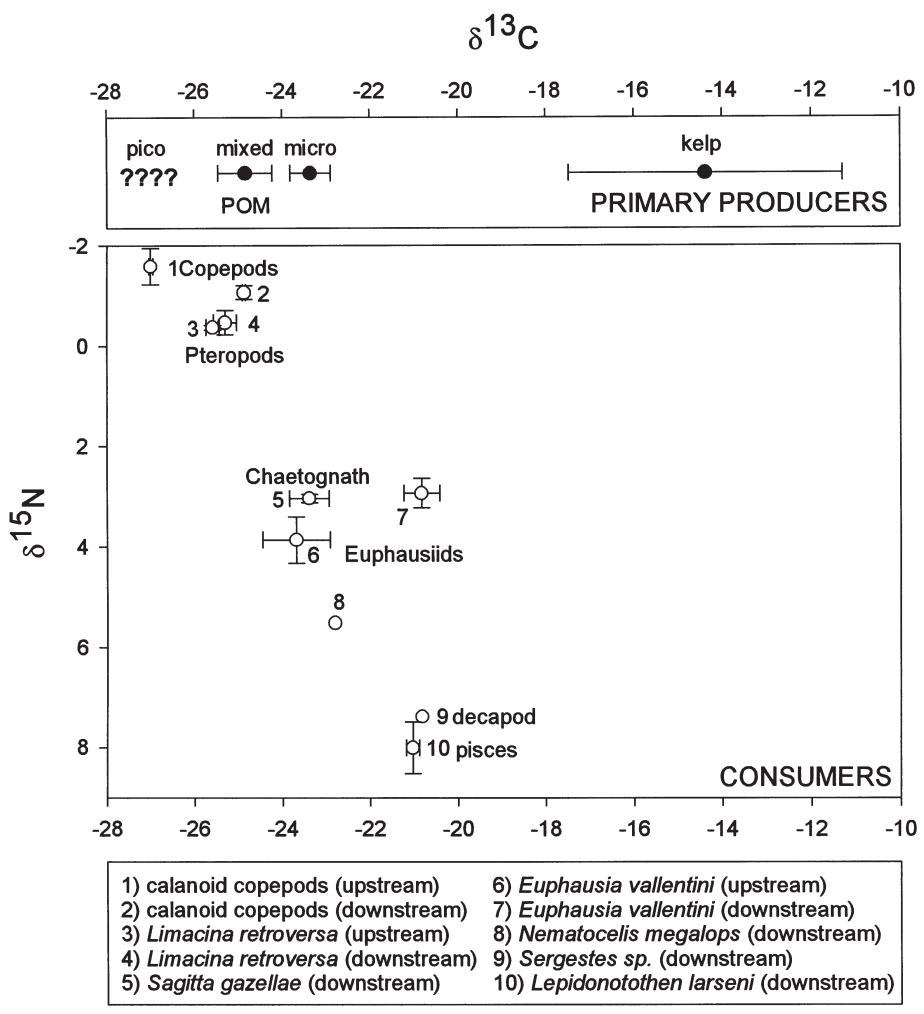

Fig. 2. Stable carbon- and nitrogen-isotope signatures of inter-island planktonic consumers and carbon signatures of primary producers that may contribute to their diets $( \pm \mathrm{SD})$ tions of the POM differed in their isotopic composition. 'Micro' POM $(>20 \mu \mathrm{m})$, had a higher $\delta^{13} \mathrm{C}$ than the mixed size fraction $(<20 \mu \mathrm{m})$ and consisted primarily of large, typically autochthonous diatoms (i.e. Chaetoceros spp., Dactyleosolen antarcticus, Fragilariopsis kerguelensis and Skeletonema costanum) and dinoflagellates (mainly Ceratium spp.). This suggests that the smaller nano and pico size fractions $(<20 \mu \mathrm{m})$, which typically predominate upstream and in the vicinity of the Prince Edward Islands (Pakhomov \& Froneman 1999b), must have had an even lower $\delta^{13} \mathrm{C}$ signature (as indicated in Figs. 2 to 4; see also Kukert \& Riebesell 1998). This smaller size fraction of the POM was dominated by small diatoms (Thalassiosira spp.), dinoflagellates (Dinophysis spp.) and coccolithophorids. Unlike the POM, downstream zooplankton (i.e. copepods, pteropods and the euphausid Euphausia vallentini) was slightly more enriched in $\delta^{13} \mathrm{C}$ than specimens of the same species taken upstream of the Island.

Both the $\delta^{13} \mathrm{C}$ and $\delta^{15} \mathrm{~N}$ of consumers exhibited a predictable enrichment with increasing trophic position, which was estimated at 1.96 and $4.11 \%$ for carbon and nitrogen respectively. Only in the zooplankton community, however, were distinct trophic levels observed. Both the benthic and the kelp-associated communities exhibited trophic continua.

Within the zooplankton community, 3 trophic levels of consumers were observed (Fig. 2). High-order predators such as decapods and the demersal fish Lepidonotothen larseni were rare. Lower-order predators such as the euphausids and chaetognaths were more abundant, while the primarily herbivorous pteropods and copepods occurred in large numbers in every trawl. The $\delta^{13} \mathrm{C}$ signature of the planktonic grazers ranged from approximately -25 to $-27 \%$, close to that of the POM, while all higher-order consumers exhibited enriched $\delta^{13} \mathrm{C}$ and $\delta^{15} \mathrm{~N}$ signatures (Fig. 2). In this planktonic community, $\delta^{15} \mathrm{~N}$ values ranged from approximately -2 to $+8 \%$, depending on the organism's trophic position.

The inter-island benthic community was dominated by suspension-feeders (e.g. bryozoans, sponges, brachiopods, hydroids) but also included a large number of predatory/scavenging species (e.g. ophiuroids, asteroids, holothurians; Fig. 3). Compared to the zooplankton community, which exhibited distinct trophic levels, benthic organisms exhibited a trophic continuum. The isotope ratios for both carbon and nitrogen were slightly enriched compared to the planktonic community, and $\delta^{15} \mathrm{~N}$ ranged from 2 to $12 \%$. $\delta^{13} \mathrm{C}$ values for primary consumers were slightly higher than that of the micro- size fraction of the POM (at -22\%).

The benthic community close to the islands $(\sim 100 \mathrm{~m}$ offshore) consisted of a range of detritivores, predators 
and scavengers (Fig. 4). There were no clear-cut grazers and instead deposit-/filter-feeders such as tanaiids and sedentary bivalves made up the lowest order of consumers (Fig. 4). The trophic pathway in this community was relatively short $\left(\delta^{15} \mathrm{~N}\right.$ ranging from $\sim 2$ to $8 \%$ ), and again no distinct trophic levels were apparent. Primary consumers exhibited a $\delta^{13} \mathrm{C}$ of $\sim 18.5 \%$, much higher than that from the inter-island communities and well above that of the POM.

Only a small number of species were found to be directly associated with kelp fronds (Fig. 4). Of these, isopods, amphipods and suspensionfeeding bivalves were the most abundant. Only 1 predator specimen was found. As with the nearshore benthic community, the trophic pathway was relatively short $\left(\delta^{15} \mathrm{~N}\right.$ ranging from $\sim 1$ to $7 \%$ ), and lowest-order consumers exhibited a $\delta^{13} \mathrm{C}$ much closer to that of the kelp than to that of the POM (i.e. $16.5 \%$ o).

Assuming a $\delta^{13} \mathrm{C}$ enrichment $(I)$ of $1.96 \%$ per trophic level, the relative contribution of kelp and POM to the diets of the different communi-

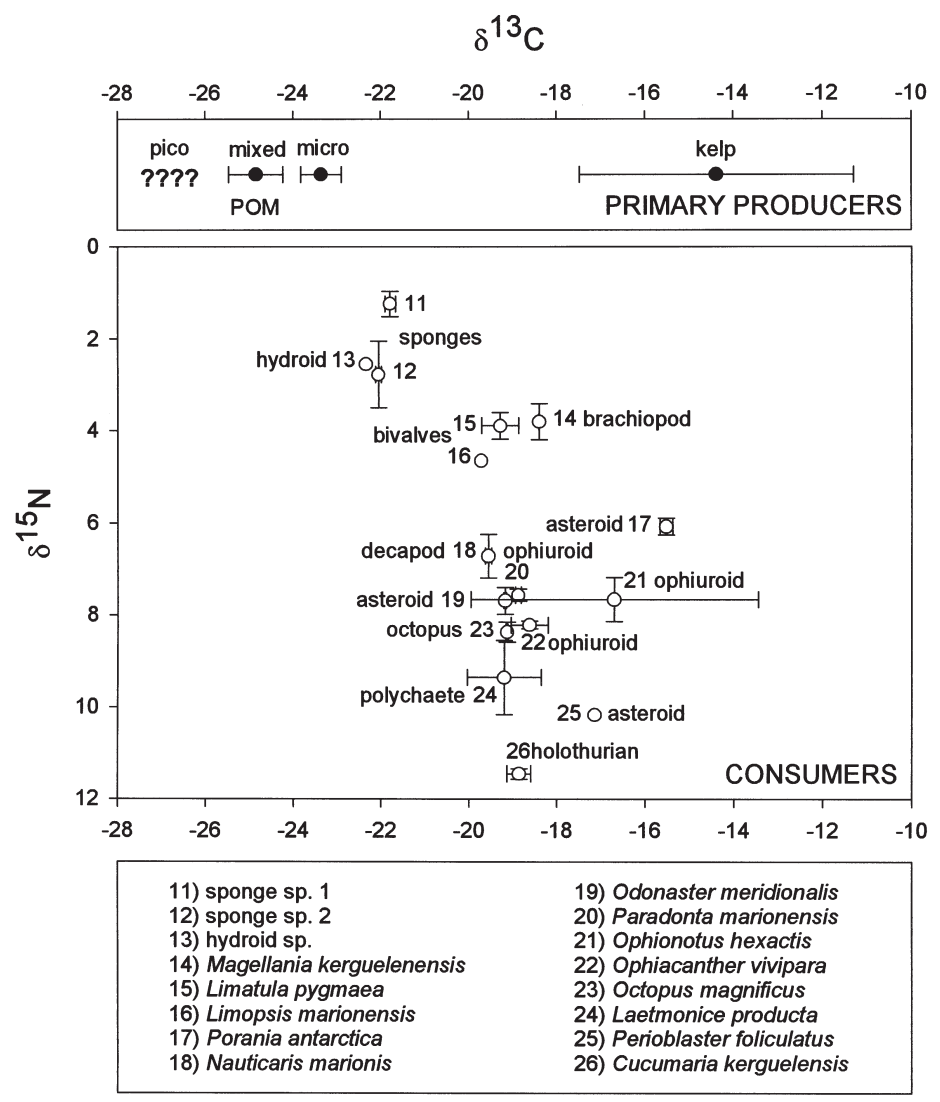

Fig. 3. Stable carbon- and nitrogen-isotope signatures of inter-island benthic consumers and carbon signatures of primary producers that may contribute to their diets $( \pm \mathrm{SD})$

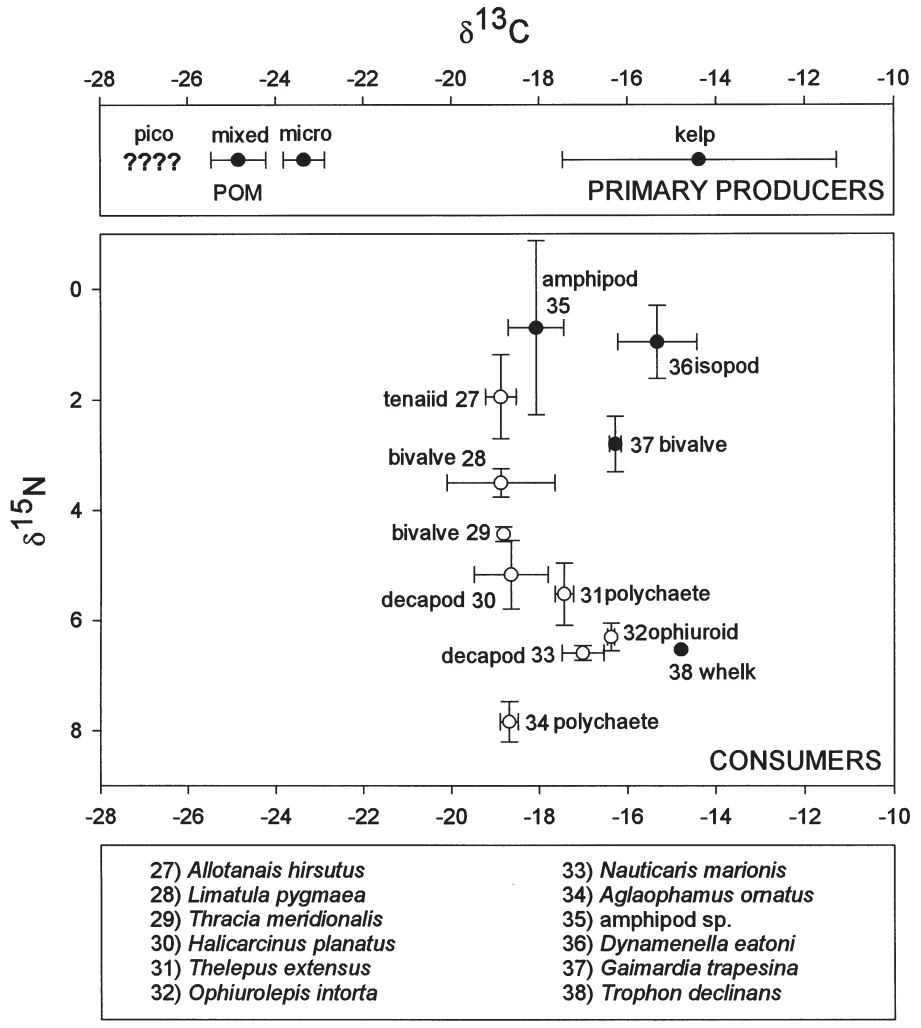

Fig. 4. Stable carbon- and nitrogen-isotope signatures of nearshore benthic $(O)$ and kelp-associated $(\bullet)$ consumers and carbon signatures of primary producers that may contribute to their diets $( \pm \mathrm{SD})$

ties may be worked out using Eq. (1) (see 'Methods'). Primary consumers from both benthic and planktonic inter-island communities have $\delta^{13} \mathrm{C}$ values very close to those of the POM ( -26 and $-22 \%$ respectively). Their expected food source (at -28 and $-24 \%$ ) must therefore consist almost exclusively of different size fractions of the POM. In contrast, nearshore primary consumers exhibit higher $\delta^{13} \mathrm{C}$ values and are likely to have consumed a mixed diet of both kelp and phytoplankton. Using Eq. (1), kelp is estimated to contribute approximately $38 \%$ of organic matter to the nearshore benthic community, while suspension-feeders and crustaceans in the kelp-associated community derive between 48 and $68 \%$ of their diet from kelpderived material.

\section{DISCUSSION}

In all 4 communities, enrichment of $\delta^{13} \mathrm{C}$ and $\delta^{15} \mathrm{~N}$ was observed with increasing trophic position, with higher-order predators such as demersal fishes, octopus and decapods having increased carbon and nitrogen stable-isotope signatures compared to their prey. The estimated average stepwise enrichment of $4.11 \%$ 
for ${ }^{15} \mathrm{~N}$ is close to that reported by other studies (Owens 1987, Wada et al. 1991, Jennings et al. 1997), while the enrichment of ${ }^{13} \mathrm{C}$ by $1.96 \%$ is slightly higher than expected from the literature (reviewed by Fry \& Sherr 1984, France \& Peters 1997). Nonetheless, the ${ }^{13} \mathrm{C}$ enrichment in this study lies well below that of other studies from the region (Monteiro et al. 1991, SholtoDouglas et al. 1991). Stepwise enrichment was particularly apparent in the offshore zooplankton community, where 4 distinct trophic levels occurred. In contrast, the benthic and kelp-associated communities exhibited no discrete trophic levels, suggesting a higher degree of omnivory (see also France et al. 1998). Nonetheless, throughout the food webs (planktonic and benthic), the ratio between carbon and nitrogen enrichment remained approximately 2 to 4 . Higherlevel consumers were, therefore, indirectly dependent on the same ultimate food source as were the grazers/ filter-feeders in their respective communities.

$\delta^{13} \mathrm{C}$ values of consumers varied greatly between communities, suggesting a different dietary composition and ultimately a different origin of organic matter. The inter-island zooplankton and benthic communities exhibited far lower $\delta^{13} \mathrm{C}$ values than the nearshore benthic and kelp-associated communities. Benthic and pelagic primary consumers in the inter-island sea exhibited carbon-isotope ratios very close to that of the POM, and it is unlikely that kelp contributed significantly to the diet of these species. This suggestion is also supported by the fact that the POM in the lee of the islands was not enriched compared to upstream POM. Kelp-derived particulate matter, with its comparatively high $\delta^{13} \mathrm{C}$ value, cannot therefore have been an important dietary component in the inter-island sea. Instead, the main source of dietary organic matter seems to have originated from phytoplankton and protozooplankton, which comprised the most abundant component of the POM (see also Froneman \& Balarin 1998).

While both benthic and pelagic inter-island communities had a diet derived from POM, they varied significantly in their carbon stable-isotope ratios. The diet of benthic suspension-feeders such as sponges and hydroids was estimated at approximately $-24 \%$, very close to that of the micro- size fraction of the POM (mainly large and/or chain-forming diatoms). In contrast the dietary $\delta^{13} \mathrm{C}$ for planktonic primary consumers (e.g. copepods and pteropods) was lower at approximately $-27 \%$, suggesting a diet of material derived from the nano- and pico- size fractions of the POM (small diatoms and flagellates).

The results presented here, as well as those from previous feeding studies (Perissinotto 1992), indicate that planktonic grazers feed primarily on allochthonous nano- and pico-plankton that predominates upstream of the islands (Pakhomov et al. 1999a). Previously unsupported is the hypothesis that 'micro' POM, which consists primarily of microphytoplankton, is an important food source driving the benthic inter-island community (Perissinotto et al. 1990, Pakhomov \& Froneman 1999). While decomposition of sinking organic matter may be expected to slightly enrich the $\delta^{13} \mathrm{C}$ of POM with increasing depth, it cannot explain a $3 \%$ increase from the pelagic to the benthic community. The possible existence of typically enriched epibenthic microalgae cannot explain the increase in $\delta^{13} \mathrm{C}$ either, as suspension-feeders dominate the community and benthic grazers rarely exceed $1 \%$ of faunal density (Branch et al. 1993, S. M. Lawrie pers. comm.). Instead, it is likely that autochthonous blooms of enriched microalgae, that at times may account for up to $80 \%$ of total chlorophyll $a$ in the water (e.g. Allanson et al. 1981, 1985, Boden 1988, Perissinotto \& Duncombe Rae 1990), are responsible for the comparatively high $\delta^{13} \mathrm{C}$ values of inter-island benthic species. Isotopic determinations of sediment samples (average $\delta^{13} \mathrm{C}=-23.82$, Kaehler unpubl. data) support this hypothesis, as benthic organic matter closely resembled that of the surface-water 'micro' POM.

Relative to the inter-island communities, nearshore consumers exhibit much higher $\delta^{13} \mathrm{C}$ values. With ultimately only 2 types of primary producers available to consumers, this pattern is probably due to an increased input of kelp-derived material. In the nearshore benthic community, lowest-order consumers (mainly deposit/suspension-feeders) assimilated organic material with a $\delta^{13} \mathrm{C}$ value expected from a $38 \%$ kelp and $62 \%$ mixed POM composition. While input of enriched animal detritus could also explain the relatively high carbon-isotope ratio of nearshore deposit-feeders, nitrogen-isotope ratios are close to those of primary consumers in other communities in this study and therefore too low to be derived from animal matter.

Animals living in close proximity to kelp had the highest $\delta^{13} \mathrm{C}$ values of all consumers. Their carbonisotope ratios indicated that in the kelp-associated community up to $68 \%$ of the diet was ultimately derived from kelp. For isopod and amphipod species that live on and can potentially feed directly off the kelp substratum, the importance of kelp in their diet is not surprising. The filter-feeding bivalve Gaimardia trapesina, however, which is attached to kelp fronds close to the water surface, may only feed on suspended matter. A large amount of kelp-derived particulate matter must, therefore, have been available in the water column. This may also be one reason for the significantly higher $\delta^{13} \mathrm{C}$ value of mixed POM close to the island, although an increase in the relative abundance of microphytoplankton may not be ruled out and could 
have partially contributed to the localised enrichment of POM.

While different size fractions of POM were the main food source for inter-island communities, autochthonous kelp-derived matter became increasingly important closer to the islands. Unlike previously suggested (Beckley \& Branch 1992), not all kelp material is, therefore, washed ashore or transported away from the islands. As such, kelp-derived material is likely to be important not only to the nearshore benthic and epiphytic communities, but also indirectly to those land-based top marine predators that feed close to the islands. Gentoo Pygoscelis papua, macaroni Eudyptes chrysolophus and rockhopper penguins Eudyptes chrysocome, for example, have all been shown to forage in inshore and nearshore waters (Adams \& Brown 1989). Large proportions of their diets ( $\geq 90 \%$ by mass for the Eudyptes spp.) consist of crustaceans such as the caridean shrimp Nauticaris marionis (Brown \& Klages 1987), which close to the islands are indirectly dependent on kelp-derived organic matter (Fig. 4). Depending on the length of their foraging trips, some land-based predators will therefore consume organic matter that is ultimately procured at least partly from kelp-derived matter. Stable-isotope analysis of the top predators would shed more light on the importance of the coupling of the land-based and nearshore marine systems.

The present study clearly indicates the useful nature of stable-isotope analysis in the investigation of foodwebs. While feeding studies may in many cases provide important quantitative information about, for example, food selectivity and feeding rates, such studies may be confounded by temporal variability in the availability of different prey species, a case in point being the apparent importance of sporadically occurring microalgal blooms to the inter-island benthic community. Furthermore, information on the sources of organic matter may be gleaned that are difficult or even impossible to obtain by conventional methods. The present study shows unequivocally that autochthonous sources of organic matter (e.g. kelp-derived matter and/or micro-phytoplankton) are important constituents of the diets of all but the zooplankton community. The latter are dependent primarily on allochthonous nano- and pico- plankton.

Acknowledgements. We are grateful to the South African Department of Environmental Affairs and Tourism and the Joint Research Council (Rhodes University) for providing facilities and/or funds for this study. Isotope measurements were made in the Goldfields/FRD/UCT stable light-isotope laboratory at the University of Cape Town, with invaluable assistance from Judith Sealy and John Lanham. Thanks are also due to staff, students and crew on the MIOS-V cruise for logistic support.

\section{LITERATURE CITED}

Adams NJ, Brown CR (1989) Dietary differentiation and trophic relationships in the sub-Antarctic penguin community at Marion Island. Mar Ecol Prog Ser 57:249-258

Allanson BR, Hart RC, Lutjeharms JRE (1981) Observations on the nutrients, chlorophyll and primary production of the Southern Ocean south of Africa. S Afr J Antarct Res 10: $13-14$

Allanson BR, Boden BP, Parker LD, Duncombe Rae CM (1985) A contribution to the oceanography of the Prince Edward Islands. In: Siegfried WR, Condy PR, Laws RM (eds) Antarctic nutrient cycles and food webs. Springer-Verlag, Berlin, p 38-45

Attwood CG, Lucas MI, Probyn TA, McQuaid CD, Fielding PJ (1991) Production and standing stocks of the kelp Macrocystis laevis Hay at the Prince Edward Islands, Subantarctic. Polar Biol 11:129-133

Beckley LE, Branch GM (1992) A quantitative scuba-diving survey of the sublittoral macrobenthos at subantarctic Marion Island. Polar Biol 11:553-563

Bligh EG, Dyer WJ (1959) A rapid method of total lipid extraction and purification. Can J Biochem Physiol 37:911-917

Boden BP (1988) Observations of the island mass effect in the Prince Edward Archipelago. Polar Biol 9:61-68

Branch GM, Attwood CG, Gianakouras D, Branch ML (1993) Patterns in the benthic communities on the shelf of the sub-Antarctic Prince Edward Islands. Polar Biol 13:23-34

Brown CR, Klages NT (1987) Seasonal and annual variation in the diets of macaroni (Eudyptes chrysolophus chrysolophus) and southern rockhopper (E. chrysocome chrysocome) penguins at sub-antarctic Marion Island. J Zool Lond 212:7-28

Bustamante RH, Branch GM (1996) The dependence of intertidal consumers of kelp-derived organic matter on the west coast of South Africa. J Exp Mar Biol Ecol 196:1-28

de Niro MJ, Epstein S (1976) You are what you eat (plus a few $\%$ ); the carbon isotope cycle in food chains. In: Geological Society of America Conference (Abstract). GSA Publications, Boulder, CO, p 834-835

France RL, Peters RH (1997) Ecosystem differences in the trophic enrichment of ${ }^{13} \mathrm{C}$ in aquatic food webs. Can J Fish Aquat Sci 54:1255-1258

France RL, Chandler M, Peters RH (1998) Mapping trophic continua of benthic foodwebs: bodysize- $\delta^{15} \mathrm{~N}$ relationships. Mar Ecol Prog Ser 174:301-306

Froneman PW, Balerin MG (1998) Structure and grazing impact of the protozooplankton community in the waters surrounding the Prince Edward Islands (Southern Ocean). Polar Biol 20:198-205

Froneman PW, Pakhomov EA (1998) Trophic importance of the chaetognaths Eukrohnia hamata and Sagitta gazellae in the pelagic system of the Prince Edward Islands (Southern Ocean). Polar Biol 19:242-249

Fry B, Sherr EB (1984) $\delta^{13} \mathrm{C}$ measurements as indicators of carbon flow in marine and freshwater ecosystems. Contr Mar Sci 27:13-47

Haxen PG, Grindley JR (1985) Durvillaea antarctica production in relation to nutrient cycling at Marion Island. In: Siegfried WR, Condy PR, Laws RM (eds) Antarctic nutrient cycles and food webs. Springer-Verlag, Berlin, p 637-640

Ismail HE (1990) Surface nutrients in the vicinity of the Prince Edward Islands during April/May 1989. S Afr J Antarct Res 20:33-36

Jennings $\mathrm{S}$, Reñones $\mathrm{O}$, Morales-Nin B, Polunin NVC, Moranta J, Coll J (1997) Spatial variation in the ${ }^{15} \mathrm{~N}$ and ${ }^{13} \mathrm{C}$ stable isotope composition of plants, invertebrates and 
fishes on Mediterranean reefs: implications for the study of trophic pathways. Mar Ecol Prog Ser 146:109-116

Kukert H, Riebesell U (1998) Phytoplankton carbon isotope fractionation during a diatom spring bloom in a Norwegian fjord. Mar Ecol Prog Ser 173:127-137

Monteiro PMS, James AG, Sholto-Douglas AD, Field JG (1991) The $\delta^{13} \mathrm{C}$ trophic position isotope spectrum as a tool to define and quantify carbon pathways in marine food webs. Mar Ecol Prog Ser 78:33-40

Owens NJP (1987) Natural variation in ${ }^{15} \mathrm{~N}$ in the marine environment. Adv Mar Biol 24:389-451

Pakhomov EA, Froneman PW (1999) The Prince Edward Island pelagic ecosystem, south Indian Ocean: a review of achievements, 1976-1990. J Mar Syst 18:355-367

Pakhomov EA, Ansorge IJ, McQuaid CD, Kohrs S, Waldron H, Hunt B, Gurney L, Kaehler S, Lawrie S, Held C, Machu E (1999a) The fourth cruise of he Marion Island Oceanographic Survey (MIOS-IV), April to May 1999. S Afr J Sci 95:420-4220

Pakhomov EA, Froneman PW, Kuun PJ, Balarin M (1999b) Feeding dynamics and respiration of the bottom-dwelling caridean shrimp Nauticaris marionis Bate, 1888 (Crustacea: Decapoda) in the vicinity of Marion Island (Southern Ocean). Polar Biol 21:112-121

Perissinotto R (1992) Mesozooplankton size-selectivity and grazing impact on the phytoplankton community of the Prince Edward Archipelago (Southern Ocean). Mar Ecol Prog Ser 79:243-248

Editorial responsibility: Otto Kinne (Editor), Oldendorf/Luhe, Germany
Perissinotto R, Duncombe Rae CM (1990) Occurrence of anticyclonic eddies on the Prince Edward Plateau (Southern Ocean): effects on phytoplankton biomass and production. Deep-Sea Res 37:777-793

Perissinotto R, McQuaid CD (1990) Role of the sub-antarctic shrimp Nauticaris marionis in coupling benthic and pelagic food-webs. Mar Ecol Prog Ser 64:81-87

Perissinotto R, McQuaid CD (1992) Land-based predator impact on vertically migrating zooplankton and micronekton advected to a Southern Ocean archipelago. Mar Ecol Prog Ser 80:15-27

Perissinotto R, Allanson BR, Boden BP (1990) Trophic relations within the island seas of the Prince Edward Archipelago, Southern Ocean. In: Barnes M, Gibson RN (eds) Trophic relationships in the marine environment. Aberdeen University Press, Aberdeen, p 296-314

Sholto-Douglas AD, Field JG, James AG, van der Merwe NJ (1991) ${ }^{13} \mathrm{C} /{ }^{12} \mathrm{C}$ and ${ }^{15} \mathrm{~N} /{ }^{14} \mathrm{~N}$ isotope ratios in the Southern Benguela Ecosystem: indicators of food web relationships among different size-classes of plankton and pelagic fish; differences between fish muscle and bone collagen tissues. Mar Ecol Prog Ser 78:23-31

Wada E, Mizutani H, Minagawa M (1991) The use of stable isotopes for food web analysis. Crit Rev Food Sci Nutr 30: 361-371

Williams AJ, Siegfried WR, Burger AE, Berruti A (1979) The Prince Edward Islands: a sanctuary for seabirds in the Southern Ocean. Biol Conserv 15:59-71

Submitted: March 14, 2000; Accepted: June 29, 2000

Proofs received from author(s): November 13, 2000 